\title{
Correction to: Association of statin use and clinical outcomes in heart failure patients: a systematic review and meta-analysis
}

Agata Bielecka-Dabrowa ${ }^{1,2+}$, Ibadete Bytyçi ${ }^{3,4 \dagger}$, Stephan Von Haehling ${ }^{5}$, Stefan Anker ${ }^{6}$, Jacek Jozwiak ${ }^{7}$, Jacek Rysz ${ }^{8}$, Adrian V. Hernandez ${ }^{9,10}$, Gani Bajraktari, ${ }^{3,4}$, Dimitri P. Mikhailidis ${ }^{11}$ and Maciej Banach ${ }^{1,2^{*}}$

\section{Correction to: Lipids Health Dis 18, 188 (2019) https://doi.org/10.1186/s12944-019-1135-z}

Following publication of the original article [1], the authors noticed a mistake in the surname of Prof. Dimitri P. Mikhailidis. In the published version, it is Mikhalidis and should be corrected to Mikhailidis.

\footnotetext{
Author details

'Department of Hypertension, Medical University of Lodz, Rzgowska, 281/ 289, 93-338 Łódź, Poland. ${ }^{2}$ Department of Cardiology and Congenital Diseases of Adults, Polish Mother's Memorial Hospital Research Institute (PMMHRI), Lodz, Poland. ${ }^{3}$ Clinic of Cardiology, University Clinical Centre of Kosovo, Prishtina, Republic of Kosovo. ${ }^{4}$ Department of Public Health and Clinical Medicine, Umeå University, Umeå, Sweden. ${ }^{5}$ Department of Cardiology and Pneumology, University Medical Center Gottingen (UMG), Gottingen, Germany. ${ }^{6}$ Charité-Universitätsmedizin Berlin, Berlin, Germany. ${ }^{7}$ Department of Family Medicine and Public Health, Institute of Medicine, University of Opole, Opole, Poland. ${ }^{8}$ Department of Nephrology, Hypertension and Family Medicine, Medical University of Lodz, Lodz, Poland. ${ }^{9}$ Health Outcomes, Policy, and Evidence Synthesis (HOPES) Group, University of Connecticut School of Pharmacy, Storrs, CT, USA. ${ }^{10}$ School of Medicine, Universidad Peruana de Ciencias Aplicadas (UPC), Lima, Peru. ${ }^{11}$ Department of Clinical Biochemistry, Royal Free Campus, University College London Medical School, University College London (UCL), London, UK.
}

Published online: 20 September 2020

\section{Reference}

1. Bielecka-Dabrowa A, Bytyçi I, Von Haehling S, et al. Association of statin use and clinical outcomes in heart failure patients: a systematic review and meta-analysis. Lipids Health Dis. 2019;18:188. https://doi.org/10. 1186/s12944-019-1135-z.

The original article can be found online at https://doi.org/10.1186/s12944019-1135-z.

*Correspondence: dpicketts@ohri.ca

${ }^{\dagger}$ Agata Bielecka-Dabrowa and Ibadete Bytyçi contributed equally to this work.

'Department of Hypertension, Medical University of Lodz, Rzgowska, 281/ 289, 93-338 Łódź, Poland

${ }^{2}$ Department of Cardiology and Congenital Diseases of Adults, Polish Mother's Memorial Hospital Research Institute (PMMHRI), Lodz, Poland Full list of author information is available at the end of the article

(c) The Author(s). 2020 Open Access This article is licensed under a Creative Commons Attribution 4.0 International License, which permits use, sharing, adaptation, distribution and reproduction in any medium or format, as long as you give appropriate credit to the original author(s) and the source, provide a link to the Creative Commons licence, and indicate if changes were made. The images or other third party material in this article are included in the article's Creative Commons licence, unless indicated otherwise in a credit line to the material. If material is not included in the article's Creative Commons licence and your intended use is not permitted by statutory regulation or exceeds the permitted use, you will need to obtain permission directly from the copyright holder. To view a copy of this licence, visit http://creativecommons.org/licenses/by/4.0/ The Creative Commons Public Domain Dedication waiver (http://creativecommons.org/publicdomain/zero/1.0/) applies to the data made available in this article, unless otherwise stated in a credit line to the data. 